\title{
michaelariens.com
}

\begin{tabular}{l|l|l|l}
\hline Home & Constitutional Law & American Legal History & Legal Ethics \\
\hline
\end{tabular}

Evidence

\begin{tabular}{|l|l|l|}
\hline Prof. Responsibility & Contact Me & Search \\
\hline
\end{tabular}

\section{Modern Legal Times: Making a Professional Legal Culture}

This essay was originally published in 1992 in volume 15 of the Journal of American Culture, beginning at page 25 .

\section{Modern Legal Times: Making a Professional Legal Culture}

\author{
Michael Ariens
}

\section{Introduction}

In the legal profession we like certain beginnings, and it is almost too easy to date the beginnings of the modern legal profession from 1870. Hubbell's Legal Directory was just one year old. The first written bar examinations were introduced in 1870. The Albany Law Journal was first published on January 8, 1870. That same month, Charles Eliot, the new President of Harvard University, appointed an 1854 graduate of the law school named Christopher Columbus Langdell to the faculty. On February 1, the first meeting of the Association of the Bar of the City of New York was held. In the summer of 1870, Oliver Wendell Holmes, Jr., was named co-editor of the American Law Review, and began his systematic study of jurisprudence resulting ten years later in the publication of The Common Law. In the fall, Langdell was named to the newly created post of Dean at the Harvard Law School. When Langdell began his Fall 1870 contracts class by asking, "Mr. Fox, please state the facts in Bryan v. Cave," the modern legal profession was underway.

This essay is a truncated history of the making of the American legal profession. In contrast to other efforts, the focus of this paper is on the creation and development of legal institutions which fostered the belief, by lawyers, in their professionalism. Legal institutions include not only law schools, bar associations and organizations like the American Law Institute but also the system of legal directories, the regional case reporter system developed by the West Publishing Company and continuing legal education groups. These institutions, which contributed greatly to the making of a distinctly professional culture in law in America, are closely related to the formation of the system of legal education first developed at Harvard Law School in 1870. While a number of institutions were created for instrumental reasons having nothing to do with legal education (like Hubbell's Legal Directory and the regional reporter system), these institutions prospered in part because of their ideological fit with the professionalizing ethos embodied Langdell's statement that "law is a science."[1]

Legal institutions, then, must be evaluated through the ideological lens which encouraged and fostered the notion that lawyers were part of a scientific enterprise. The perception that law was a science, and lawyers scientists, altered the shape of the legal profession; this shape was further altered by the development of legal institutions which assumed the science of law, which thus greatly changed the relationship of the legal profession to American society. My intention is to examine several legal institutions which assisted in the transformation of lawyers into such a powerful profession. However, I am not asserting 
that the making of the modern legal profession is simply the result of the creation of law schools based on the Harvard model. My goal is to recognize the expanding sphere of influence the American system of legal education had on the American bar.

This essay will first trace the development of legal education beginning in 1870, for the creation and entrenchment of a university — and post-baccalaureate-based legal education was the catalyst for many of the developments which followed. I will then examine the creation and development of selected legal institutions in modern legal times in light of the history of legal education and their impact on the legal profession. This essay will make much of the fact that disparate but related events occurred at approximately the same time. I make this point for two reasons: it satisfies a need lawyers have for order and making sense of things, and it enables me to tell a better story.

\section{Modern Legal Education[2]}

The modern law school is based on the nineteenth century notion that law is a science. On two occasions, in 1871 in his Preface to the first American casebook, Cases on Contracts, and in 1886 on the Commemoration of the 25th Anniversary of the founding of Harvard University, Langdell discussed the idea of law as a science.

Law, considered as a science, consists of certain principles or doctrines. To have such a mastery of these as to be able to apply them with constant facility and certainty to the evertangled skein of human affairs, is what constitutes a true lawyer, and hence to acquire that mastery should be the business of every earnest student of law.... But the cases which are useful and necessary for this purpose at the present day bear an exceedingly small proportion to all that have been reported. The vast majority are useless, and worse than useless, for any purpose of systematic study. Moreover, the number of fundamental legal doctrines is much less than is commonly supposed: the many different guises in which the same doctrine is constantly making its appearance, and the great extent to which legal treatises are a repetition of each other, being the cause of much apprehension. If these doctrines could be so classified and arranged that each should be found in its proper place, and nowhere else, they would cease to be formidable from their number.

[It] was indispensable to establish at least two things, first that the law is a science: secondly, that all available materials of that science are contained in printed books. If law be not a science, a university will best consult its own dignity in declining to teach it. If it be not a science, it is a species of handicraft, and many best be learned by serving an apprenticeship to one who practices it. If it be a science, it will scarcely be disputed that it is one of the greatest and most difficult of sciences, that it needs all the light that the most enlightened seat of learning can throw upon it. Again, law can be learned and taught in a university by means of printed books.... [I]f printed books are the ultimate sources of all legal knowledge; if every student who would obtain any mastery of law as a science must resort to these ultimate sources: and if the only assistance which is possible for the learner to receive is such as can be afforded by teachers who have travelled the same road before him.- - then a university, and a university alone, can furnish every possible facility for teaching and learning law.... We have also constantly inculcated the idea that the library is the proper workshop of professors and students alike; that it is to 
us all that the laboratories of the university are to the chemists and physicists, all that the museum of natural history is to the zoologists, all that the botanical garden is to the botanists.[3]

Langdell's conviction that law was a [natural] science justified a number of radical changes in approaches to law: first, law was best learned in school, not as an apprentice to a practicing lawyer: second, law consisted of a relatively small number of legal principles, and the mass of material incorporated in treatises written and used by lawyers was useless: third, only an expert (i.e., professor) dedicated to the study of law, could effectively master and impart those difficult principles of law: fourth, since the law was based on a small number of legal principles, the implicit assumption was that the law should be uniform throughout the United States, and law schools were to teach a form of "nationalized" law which transcended any particular state law rules: and fifth, the scientific approach was based on analyzing the "right" cases in search of the basic principles of law, cases selected by the professor to form a casebook; an attempt by the professor and the class to analyze these cases took the place of lectures by the professor.

Langdell's vision appeared both an intellectual advance compared with either the apprenticeship system or the pedagogical system of lectures, and cost-effective. By analogizing law to science, Langdell encouraged the belief that prospective lawyers needed expert and systematic training, training largely not available in an apprenticeship. Langdell also believed that a proper "Socratic" interchange between the teacher and one student concerning a case would better teach legal principles not only to that student but also to the rest of the class. That is, there was no need for a student to participate in the exchange in order to grasp the scientific principles adduced during the exchange. Therefore, a large class of students could learn as effectively as a small class of students. A student-teacher ratio of 75:1 permitted the university (and law school entrepreneurs) to view a law school as profitable, and from 1870-1890 the number of law schools doubled. In the succeeding twenty years the number again doubled.

Langdell's unifying perspective also created a new addition to the legal profession: the legal mandarin. In 1873, Langdell convinced the Harvard Board of Overseers to approve a five year contract for James Barr Ames to teach at the law school. Ames had graduated from Harvard in 1872 and obviously had little practical experience at the bar. However, Ames had been one of Langdell's first acolytes and had excelled as a student at Harvard. If law was a science, Ames's lack of experience was not a hindrance to his teaching ability, for the principles of law were found in the library, not in the practice of law. Instead, the daily practice of law often caused the practitioner to lose sight of the scientific principles undergirding law, which would make a practitioner less suitable as a law teacher. While Harvard continued to hire retired judges and practicing attorneys to teach, the hiring of the inexperienced but academically successful Ames signaled another development created as a consequence of Langdell's theory, a development which dominates the present legal academic world. At the same time, events in the legal profession made law schools a much more attractive place to educate future lawyers than apprenticeships.

First, law schools appeared to better assist prospective lawyers in entering the legal profession. Beginning in 1871, the state of New York limited entry into the profession to those who both passed a public examination and complete either three years of apprenticeship in a lawyer's office or one year of law school. In addition, Albany and Columbia law school graduates were statutorily granted a diploma privilege, which exempted them from the public examination requirement because they had received law 
degrees. Some prospective lawyers attended law schools rather than apprenticing in law offices because they perceived the legal science taught in law school as better preparation for a public (and, beginning in 1877, a written) examination. The diploma privilege available in New York and other jurisdictions also encouraged prospective lawyers to attend law school. Finally, the New York statute permitted applicants educated for one year at law school to take the bar examination while requiring a three-year clerkship for those not attending law school, which indicated another bias favoring law schools over apprenticeships.

Second, in August 1878, the American Bar Association (ABA) was founded in Saratoga Springs, New York.[4] The progenitor of the Association was a Connecticut lawyer and Yale Law School graduate, Simeon Baldwin. Baldwin's interest in a national bar association was intimately related to his conviction that learning law was best accomplished in a graduate legal education. Among the purposes listed by the founders of the ABA in Article I of its constitution were advancing "the science of jurisprudence" and upholding the honor of the legal profession. This latter provision meant, according to Professor Matzko, "raising standards of legal education and admission to the bar." The next year the ABA founded a standing committee on legal education to effectuate that goal. Supporting legal education and disparaging legal apprenticeships was a prominent goal of the ABA, and this goal was based in part on fostering the science of jurisprudence. The year before the ABA organized, the New York State Bar Association was founded. One of its stated purposes was to "cultivate the science of jurisprudence."[5] This unity of purpose among Langdell and bar organizers like Baldwin may have covered disagreements about the utility of the case method in understanding the science of jurisprudence, but the broader goal of viewing law as a science subsumed those narrower pedagogical differences. While the ABA never accounted for more than a tiny percentage of lawyers during the nineteenth or early twentieth century, its membership consisted of the "elite" members of the bar and its influence far outstripped its size.

Third, by 1886, when Langdell spoke at the 250th anniversary of Harvard's founding, the university-based, scientific approach to legal education begun at Harvard Law School was clearly a success. While the Harvard Law School had seen its enrollment drop to a very low level in the 1882-83 academic year, by 1886 the law school had seen its enrollment surge and had achieved some degree of financial support from alumni. That same year, elite New York City practitioners and pre-1870 Harvard Law School graduates James Coolidge Carter and Joseph $\mathrm{H}$. Choate signed a circular pledging financing support for the law school, and Louis D. Brandeis organized, as Secretary, the Harvard Law School Association, an alumni fund-raising organization dedicated to the financial support of the law school. This financial support from influential practitioners in Boston and New York secured Langdell's approach from any attack by other disenchanted alumni. Financial support also could be used to convince prospective students that law school generally, and the case method in particular, were viewed favorably by successful practitioners.

Fourth, technological changes, including the telephone and the typewriter, made the apprenticeship system less important to the profession.[6] Finally, the exponential increase in the 1870 s and 1880 s of published case reports necessitated the creation of a group of experts capable of organizing and critiquing this explosion of law.

By the turn of the century, legal education had triumphed over the apprenticeship system. More specifically, the case method of instruction had triumphed over the lecture method. While requirements concerning the among of pre-legal education necessary to enter law 
school and the period of study necessary in law school were debated through the 1920s, the law school had become the center for learning law. One example of the maturity of the law schools was the creation in 1900 of the Association of American Law Schools. The AALS was created by the "better" law schools to differentiate themselves from the mass of law schools. It additionally cemented the differences between the practitioner and the legal academic.

The American law school has changed little since its initial triumph in 1900. While there is a greater variety of courses, teaching methods and approaches to law offered in today's law schools, the structure of the law school remains remarkably the same. Law school is a three-year program, the first year of which largely consists of private law courses taught to large classes through the primary text of a casebook by an academic whose experience in the practice of law is limited. Approximately ninety percent of all ABA-accredited law schools are affiliated with universities which are members of the AALS and require applicants to possess a college degree before matriculating (the rest require at least three years of college work). Most of the students' work after the first year will consist of more case-oriented courses and library-based research. Clinical offerings are spotty and often not considered part of the "main" curriculum.

American legal thought since Langdell also has largely adopted (and adapted) the view that law is a science. The founder of sociological jurisprudence, Roscoe Pound, later Dean at Harvard Law School, believed that while law was an instrument to obtain justice and not an autonomous realm, it remained a science. The American legal realists of the 1930s, who deprecated Langdell's formalism and Pound's sociological jurisprudence, also believed that law was a science: in their view, however, law was a social science rather than a natural science. The post-World War II jurisprudential theories of reasoned elaboration and law and economics concluded that law was a rational science. It has only been in the past fifteen years that law has been viewed as non-scientific.

Turning lawyers into a professional class required more than the incantation that "law is a science." One requirement was to progressively tighten admission standards for the practice of law. Law schools contributed to the making of the profession first, by displacing the apprenticeship system and second, by regulating themselves and the students they admitted and graduated. While the first goal was achieved by 1900, the second goal required the creation of several institutions.

The most important institution created by law schools which markedly affected the making of a legal profession was the Law School Admission Test. The 1920s were a tumultuous time for legal education and the legal profession, and one "professionalizing" method was the creation, at Columbia Law School, of a legal aptitude test which followed closely in time the development of general aptitude tests. The test, given from 1921-24, tested abstract reasoning and the ability to deal with symbols and was given "to avoid the human waste of allowing men without requisite capacity to embark upon studies at which they were doomed to fail."[7] The Columbia test was followed by the Ferson-Stoddard Law Aptitude Examination in 1925, which was adopted by nine schools. Yale Law School instituted an aptitude test in 1931. Other schools, including the Universities of California, Michigan and Iowa, began using aptitude tests before the end of World War II.

The idea of creating an organization to implement uniform admission standards was first brought to the attention of the AALS in 1938. It was only after the end of World War II, however, that a Conference on the Legal Aptitude Test met and the Law School Admission 
Test (LSAT) was implemented. Columbia's Legal Aptitude Test (the Lorge examination) successfully distinguished the poor student from the rest of the applicants but was considered unsatisfactory because it did not distinguish between the "good" applicant and the "excellent" applicant. In 1947 Columbia convinced Harvard and Yale to join it in financially supporting an examination drafted by the College Entrance Examining Board. The first Law School Admission Test was given experimentally to first year law students at seven law schools in 1947. In 1948, the LSAT was given to students in time for use in admitting students for the 1948-49 academic year. Within ten years the number of LSAT examinations administered exceeded the number of first year law students enrolled in law schools, and the LSAT eventually became one of the two "objective" criteria by which students were selected for admission at all law schools.

An examination which permitted Columbia to distinguish between the good and the excellent candidate allowed Columbia and other schools to better market their students to law firms in New York and elsewhere, thus to attract more "qualified" students and to attract more law firms and (maybe) more funds for the school from alumni grateful that their diploma was increase in "value." This cycle of success prodded other law schools to compete with Columbia by being more selective in admitting students. This, combined in the 1960s and 1970s with a tremendous increase of persons interested in becoming lawyers, led to high entry barriers into law school and into the legal profession.

By making the LSAT a prerequisite to admission to any law school, entry into law was further "professionalized" to the extent that it appeared that law school admissions were merit-based. Entry into the profession was regulated by the nearly universalized requirement that students be graduates of a law school, and a law school admission was regulated by admitting only those who performed well on this "objective" test. One way in which the LSAT was deemed merit-based was by relying on empirical studies which have shown that there is some correlation between LSAT score and first-year grades. By assuming the relevance of first-year grades to the making of a competent lawyer, the LSAT is made more objective. Of course, there is no empirical study showing that the competency of a lawyer is based on their first-year grades. It is simply assumed that law school teaches students in the science of jurisprudence, and it is particularly assumed that the Langdellian-based first year of law school teaches the science of law. The acceptance of the LSAT, then, by law schools as well as by law firms is an acceptance of the system of legal education based on Langdell's ideas. There is no evidence (and I doubt there could be any such proof) correlating LSAT scores with lawyerly competence or ability.

The stature of the legal profession was enhanced as entry requirements into law schools were raised. In the last fifty years, since lawyers attend law school (almost always) only after graduation from college, the seven years of education after high school could be used to justify the power and income (and maybe prestige) of lawyers. Beginning after World War II, law schools admitted only those students who deserved admission based on the objective criteria of their undergraduate grade point average and LSAT score, which reinforced notions of selectivity in entry into the legal profession.

Making lawyers professionals required the development of a number of other institutions, many of which were related to Langdell's belief that law was a science. In the next section I will discuss a few of those institutions which have helped create present perceptions of the American legal profession.

\section{Modern Legal Institutions}




\section{Uniformity and Legal Institutions}

Cultivating the science of jurisprudence and enhancing the status of its members also led the ABA to include in its initial list of purposes the goal of uniformity in law. By asserting that there existed only a few principles of law and by compiling a list of (mostly English) cases from which to derive those principles, the legal science of Langdell implicitly assumed that there should be a uniformity of law. One of the most persistent ideas in modern American law is that uniformity of law in the United States is both desirable and capable of accomplishment.

In 1881, the Alabama State Bar proposed to the ABA and other state bar associations that they support efforts to create uniformity in law throughout the states. No action was taken until 1889, when the ABA created a Committee on Uniform State Laws, consisting of one member from each state. The next year the New York state legislature passed an act authorizing the governor to appoint three commissioners whose duty it was to study uniformity. The ABA immediately passed a resolution calling for all states to pass an act similar to the New York act. In 1892, commissioners from eight states attended the first meeting of the Commissioners of Uniform State Laws, held at the same time as the annual ABA meeting.

The first effort of the organization, which altered its name in 1896 to the National Conference of Commissioners on Uniform State Laws, was a Uniform Negotiable Instruments Law, adopted by the Conference that same year. According to Harvard Law School historian (and Professor) Arthur Sutherland, Harvard Law School Dean James Barr Ames, author of Cases on Bills and Notes, was unaware of the existence of the Uniform Negotiable Instruments Law until four states had already passed the law. Ames, who had succeeded Langdell as Dean at Harvard in 1895, criticized the uniform law in an article published in the Harvard Law Review in 1900. By this time, the uniform law had been enacted by fifteen states and Congress. Ames's criticism was that the technical drafting defects of the law required its abolition. This article sparked a law review debate between Ames and the President of the Conference.

While Ames lost the battle (the Negotiable Instruments Law was eventually enacted by every state), he, on behalf of legal academics, won the war. Ames was appointed a Commissioner on Uniform Laws by the Commonwealth of Massachusetts in 1902, and the Conference shortly thereafter appointed Harvard Law School Professor Samuel Williston to draft the Uniform Sales Act, adopted by the Conference in 1906. By 1910, Williston had further authored or co-authored for the Conference the Uniform Warehouse Receipts Act, the Uniform Bills of Lading Act and the Uniform Stock Transfer Act. Williston was the first of a long line of academics, largely academics at "elite" law schools, who have been asked to lend their expertise to uniform or model legislation.

Two patterns emerged from this delegation of authority by practitioners to academics: First, the Acts required interpretation, which academics offered by writing treatises and other interpretive guides for use by practitioners. Williston followed his work on the Uniform Sales Act with a 1909 treatise on the law of sales, in large part a commentary on the Uniform Sales Act. Williston later followed his work as Reporter for the Restatement of Contracts with a multi-volume new edition of his treatise on contracts. Second, it confirmed two views: one, that uniformity in law was possible and two, that legal academics, as the scientists of the legal profession, were in a better position than practitioners to guide efforts to make uniform law. 
The profession's efforts to make law more uniform was a consequence of the gradual acceptance, within and without the law school, that law was a science. It was also a response to the realization that decisions by courts in the different states were not uniform, a realization caused by the publication by West Publishing Company of all the cases decided by the highest court of each of the states. These efforts eventually led to the formation of the American Law Institute in 1923.

In 1914, when the Association of American Law Schools and the American Bar Association first held their annual meetings separately, the president of the AALS suggested the creation of a juristic center. It was not until 1920, after the end of World War I, that the idea was revived. The proposal to revive a juristic center was analogized to the Commonwealth Fund which that same year had organized a Legal Research Committee to aid legal reform. The nature and scope of the center was altered in the intervening years, and in February 1923, the first meeting of the American Law Institute (ALI) was held in Washington, DC before an unprecedented gathering of the nation's legal elite, including Elihu Root, the first President of the ALI, and William Draper Lewis, the first Executive Secretary of the ALI.

Shortly before the formation of the ALI, Root and Lewis had suggested to the bar a uniformity of another sort: uniformity of legal education. The AALS and the ABA had both attempted to induce some stringent regulation of law schools since 1900. In 1910, the Carnegie Foundation published the Flexner Report, which examined the education offered by all medical schools. The medical profession used the Flexner Report to influence states to close some medical schools, raise admission standards and the quality of medical schools and to enhance their professional status. In the forty years since Langdell had become Dean at Harvard, the number of law schools had quadrupled to 124. In 1913, the ABA's Section on Legal Education invited the Carnegie Foundation to undertake a similar study of law schools. Alfred Z. Reed, a non-lawyer, was assigned to the study. While Reed was visiting law schools and readying his report, professors whose schools belonged to the AALS packed the 1920 meeting of the Section on Legal Education of the ABA and caused the appointment of a Committee on Legal Education. This committee, chaired by Elihu Root, prepared a report adopted the next year which declared that (1) law school was the only place to obtain an adequate legal education, (2) two years or university studies were a necessary prerequisite to law school admission and (3) the diploma privilege was formally disapproved.

A month after Root's report was published, Reed's study, Training for the Public Profession of the Law, suggested that uniform standards for law schools would not benefit either the profession or the public(s) the profession served. Reed noted that the legal profession was presently a diverse profession: since American society was growing more pluralistic, this diversity in the profession was to be encouraged, not suppressed. Consequently, the training of lawyers by different kinds of law schools with different goals and missions was beneficial to society.

Neither the ABA nor the AALS approved of Reed's study and both took steps to create uniformity in the legal profession. Beginning in 1923, in the same year as the founding of the ALI, the ABA began accrediting law schools based on uniform standards to be applied to all law schools. While at first this had little coercive impact on law schools, the ABA began encouraging states to limit the bar examination to persons who were graduates of ABA-accredited law schools. In 1935, only nine states required an examinee to have 
graduated from an ABA-accredited law school while in 1984, forty-eight states had such a requirement.[8] The AALS also progressively toughened its accreditation standards while encouraging schools to join the association. The AALS, through individual professors at several of its most prominent institutions, also assisted in creating uniformity through the ALI's Restatement project.

The purpose of the ALI was to clarify and simplify the common law via a Restatement of the Law. When completed in 1944, the project to restate the law encompassed the restatement of the law of Agency (1923-33), Conflict of Laws (1923-34), Contracts (1923-32), Restitution (1923-37), Torts (1923-39), Property (1927-44), Trusts (1927-35), Security (1936-41) and Judgments (1940-42); it is undoubtedly the most successful effort to alter law in American legal history. The certainty by which most of the Restatements declared the correct law, their impeccable establishment credentials and the timing of the publication of the Restatements made them an instant success.

The cases published by West evidenced an inescapable problem which the restatements were to resolve in a federal system in which opposing or inconsistent legal rules existed side by side. How did lawyers or judges capable of choosing between these inconsistent rules justify one as correct and the other as incorrect? The Restatement of the Law was designed to provide an answer to which those perplexed lawyers and judges could turn. The Restatements drafted and approved by the ALI consisted literally of black-letter rules followed by illustrative commentary and examples. The black-letter rule enunciated by the Restatement was intended to give lawmakers a confidence that their decisions would be correct. Additionally, society could be confident of the correctness of the restated position because of pre-eminence of the drafters of the restatements. The committee assigned to prepare a particular restatement consisted of prominent practitioners, judges and an occasional professor. The Reporter for the committee, the person who ordinarily drafted the Restatement, was almost always a law professor, the expert in the field. After the Reporter prepared a draft of the Restatement, it would be debated by the committee and the ALI Council and only after a lengthy, time consuming process would the draft be approved. This bureaucratic structure, giving experts the power to decide the "law," served as a purportedly neutral, objective basis for courts to adopt the restatement rule and to reject any contrary legal rule.

The belief in the neutrality and objectivity of the Restatements was important because of the timing of their publication. The Restatements were published between 1932 and 1944, with the bulk published in the 1930s. This timing was propitious for two reasons: First, the Restatements were themselves a response were themselves a response to the charge that legal rules had no intrinsic meaning, a charge made by a number of legal academics who were grouped together as legal realists. This charge, in its most serious vein, was that the rule of law was a myth; judges decided cases in a subjective politicized manner, not as objective law (or rule) abiding magistrates. This realist attack eliminated any possibility of certainty in the law. Second, the Great Depression and the growing interest in socialistic and regulatory solutions to end the depression threatened the largely conservative order in which the legal profession had a great stake; the Restatements of the Law were conservative legal responses to societal changes because they assumed the dominance of judge-made common law.

The acceptance by the profession of the Restatements was immediate. The individual restatements were cited in support of appellate court decisions thousands of times after their adoption. The ALI eventually compiled a work which noted the citations in cases to 
provisions of the Restatements.

As the work wound down in the late 1930s and early 1940s, the ALI began working on model codes. Here, its success was much more limited: for example, the Model Code of Evidence, proposed in 1942, was not adopted by any state. The ALI had more success when it worked with the National Conference of Commissioners on Uniform State Laws. Their joint effort to fashion a Uniform Commercial Code (UCC) resulted in the adoption of the UCC in all states except Louisiana.

The success of the Restatement of the Law, however, lasted only a for a short time. In 1953, a mere nine years after the adoption of the last Restatement, the ALI began working on a Second Restatement of the Law. Since "United States judges no longer believe that stare decisis demands slavishly following earlier decisions," it was necessary to again restate the law in order to ensure the relevance of the restatements.[9] The result was a Restatement (Second) and, currently, the beginnings of a Restatement (Third). Unlike the Restatement (First), which was designed to create certainty in law, the project of the Restatement (Second) was to restore the autonomy of law from politics by acknowledging but limiting (through the rules of the Restatement) the discretion granted judges. This alteration in the Restatement project, however, did not affect the overarching view that uniformity in law was both possible and desirable. Law remained a science.

A final example of uniformity is the bar examination. In 1870, a written bar examination existed only in some counties in Massachusetts. By 1931, when the National Conference of Bar Examiners (NCBE) was created, thirty-eight states required passage of a written examination and ten states required bar applicants to pass some combination of written and oral examination. Part of the reason for the NCBE's existence was to ensure the "professionalism" of lawyers by making more uniform bar examination requirements among the states. The NCBE first wielded power uniform the character investigation of a lawyer who applied to another state for a license to practice law. It also worked to make uniform other aspects of licensure, like the type and form of the bar examination. In 1972, the Multistate Bar Examination (MBE) was first introduced as part of a bar examination. Today, the MBE is used by nearly all jurisdictions as a substantial part of their examination. The Multistate Professional Responsibility Examination (MPRE), introduced in March 1980 and then required by six states, is now required by forty jurisdictions. Additionally, several states have expressed an interest in adopting the Multistate Essay Examination (MEE), introduced in 1988.

The interest in uniformity in bar examinations has not led to a uniform-or even national-bar. Instead, uniformity has led to the creation of bar review organizations such as BAR/BRI and PMBR, organizations which teach law school graduates how to pass the various bar examinations. The organizations' lectures are given almost exclusively by law professors (and several bar review organizations were in fact started by law professors). This profitable business allows law schools to continue to say they teach students the science of law, gives law professors the opportunity to earn extra income for teaching bar review courses and allows the profession to insist to the public (without any empirical evidence) that bar examinations test competence, thus providing a method of quality control.

\section{Legal Publications}

In 1870, the Albany Law Journal, a weekly newspaper for lawyers, joined the monthly 
American Law Register and the quarterly American Law Review as commercial periodicals devoted to the legal profession.[10] The Albany Law Journal was not intended as a local paper; it succeeded as a national journal of the legal profession, thus contributing to the perception of a unified legal profession. The success of the Albany law Journal inspired others to start law-related journals, including the Central Law Journal, based in St. Louis, and a number of other law journals in America's larger cities. These other journals, like nascent state and local bar associations, encouraged professionalism. One stated goal of these periodicals was to improve the image of the legal profession; it actually may have done so by informing lawyers of the most recent decisions handed down by the courts.

A year after the appearance of the Albany Law Journal, the company that is now Lawyers Cooperative/Bancroft-Whitney began publishing a series of selected leading cases from the states with annotations. These American Reports were a handy guide to understanding the most "important" cases recently decided. Five years later, two brothers started reporting selected cases decided by the Minnesota Supreme Court. As early as 1878, the brothers were publishing all the cases in Minnesota and five adjoining states in the Northwestern Reporter.

The West Publishing Company expanded in 1887 to publish, in seven regional reporters, all of the decisions of the highest court of each state in the country. It also published the decisions of the federal courts. That same year, a group of industrious students at the Harvard law School, buoyed by the 1886 commemoration of the 250th anniversary of Harvard University and the founding of the Harvard Law School Association, decided to publish a review of law. These events were crucial to creating a professional image for lawyers in several respects. First, the publication of regional reporters both democratized and professionalized lawyers. Regional reporters and commercial law journals democratized lawyers by giving them easier access to a greater number of analogous cases; it professionalized lawyers by permitting courts to require lawyers to undertake a greater amount of research when the case involved difficult or unsettled legal issues. For example, by the time of the publication of the First Decennial Digest in 1897, West Publishing Company (possibly in an effort to market the Digest) claimed that there were over half a million reported cases. Second, the publication of all reported cases placed greater pressure on appellate court judges to justify their decisions, either on substantive (legal) grounds, or on procedural (standards of review) grounds. The development of law journals, especially student-run law reviews, also affected the decisions of appellate court judges, for these journals provided a forum for a more searching criticism of recent decisions by both authors of articles and student editors. Third, the regional reporters provided an overflow of data for lawyers to comprehend, which privileged the organizational knowledge of professors whose treatises and casebooks attempted to systematize the data, and made more attractive the view that law was a science consisting of relatively few principles. One result of the effort to systematize the data, as discussed above, was the founding of the American Law Institute. Thus, the organizing and systematizing of the common law was left in the hands of the legal academics.

The creation of the student-run law review also contributed to the pre-eminence of professorial commentary. Purportedly meritocratic, the law reviews limited membership to students at the top of their class. That is, only those students who thought most like their professors would be admitted to the law review. This meant that the students operating the law review were of a similar mind as their professors, which skewed the views afforded the publication. Second, the class of legal professionals who enjoyed the most time to write for these reviews were law professors, thus giving the professor another forum for advancing 
his views.

While the Albany Law Journal, the Central Law Journal, the American Law Register and the American Law Review and most other commercial law journals ceased publication early in the twentieth century, the law school-based law review proliferated. While there existed only two law school-based law reviews before 1900, nearly every law school today has at least one (and often more than one) review edited by law students. This imitation of the Harvard model has encased a review structured by Langdell's maxim, for the usual output of a review consists of one or more articles written by law professors and one or more comments and case notes critically reviewing an aspect of law written by students.

\section{Continuing Legal Education}

Law schools claim to teach their students in legal reasoning. To better teach students in the science of law and legal reasoning, the non-practicing professor contributed to the profession by writing a treatise or casebook, the later being largely a compilation of "relevant" appellate cases. In 1932, Jerome Frank, whose 1930 book Law and the Modern Mind had challenged the objectivity of judicial decision-making, suggested that the law school, in part because of the casebook method of studying appellate decisions, had become too academic and Langdell's "false dogmas" needed to be repudiated. Frank's plea for clinical programs in law schools was largely ignored until the 1960s and later. Instead of reforming or transforming legal education, other institutions began supplementing the education of students in law school. Larger law firms were able to supplement the "scientific" education of new lawyers by training their new associates in programs designed by the firm for the benefit of the firm. In the 1930s, however, most law firms could not afford the costs associated with this training program. In the depths of the Depression, a New York City practitioner named Harold Seligson found a niche offering a "practical" education in law. Seligson offered Practising Law Courses taught by four practitioners. In 1936, nine courses were being taught by forty practitioners covering 180 hours of instruction. Lawyers interested in the program began by attending sixty hours (thirty two-hour sessions) of general courses and then "graduating" to specialized courses. Seligson's "Practicing Law Courses" were then organized under the banner of the Practising Law Institute (PLI).

Seligson informed the ABA about PLI's efforts regarding continuing legal education in the late 1930s, and while the ABA resolved to sponsor such a program, no action was taken until after World War II. In 1946, the ABA decided to sponsor a national continuing legal education program. It chose not align itself with PLI but with the ALI, and ALI-ABA continuing legal programs began in 1948. The greater national reputations of both the ALI and the ABA effectively restricted the PLI to programs in New York for the next twenty years.

The displacement of PLI by ALI-ABA was an attempt to alter the goal of continuing legal education from training the new lawyer in the "practice" of law to making experienced lawyers better "experts" in specialized fields of law. Four reasons explain the change: First, the establishment-oriented ALI and ABA, as strong supporters of the three-year universitybased, casebook-saturated law school, were opposed to officially recognizing a grievous fault in legal education, that is, the failure to train lawyers how to practice law. The ABA, after all, accredited many of these law schools, thereby putting its reputation on the line, and the ALI consisted largely of graduates of and professors from "elite" law schools who fervently supported the system structured by Langdell. Second, the explosion in law 
created by the entrenchment of the administrative state, as well as developments occurring in "private" law, required a much greater need for lawyers by those businesses subject to federal regulation and changes in the common law. Third, the PLI was created when the national bar passage rate was less than fifty percent, and economic hard times made it difficult for many of those who had entered the profession to find jobs (or to find work as self-employed sole practitioners). In contrast, the national bar passage rate in 1948, near the beginning of America's long economic boom, was sixty percent, and the benefits from the GI bill gave students an incentive to attend an ABA-accredited law school rather than an unaccredited law school. Fourth, the teaming of two widely recognized legal organizations for the purpose of sponsoring continuing legal education programs would create a competitor so large and powerful that it would dominate the market.

There are three other developments in the legal profession which affected continuing legal education: graduate legal education leading to the Master of Laws (LL.M.) or other degrees, making mandatory to continued licensure continuing legal education (CLE) and the advent of legal specialization.

By the 1930s, a number of schools had programs allowing a person who had received a Bachelor Laws (LL.B., now a J.D.) degree to spend one year as a graduate student and receive a graduate law degree. These programs were designed for two purposes: training future law teachers and training lawyers in a specific area of practice. To train future law teachers by inviting them to spend a fourth year in law school confirmed the belief that law was understood best in the classroom and library, as Langdell had suggested.

The interest in training lawyers in a specific area of practice was the result of several factors. First, the graduate law degree eventually became a shortcut for attorneys interested in becoming experts in number of legal fields which burgeoned with the creation of the administrative state. The degree itself became "proof" of the attorney's expertise in a given legal practice specialty and thus differentiated the attorney in the legal marketplace.

Second, the majority of graduate programs opened in the last twenty-five years offer an opportunity for law schools to earn an enormous profit, since most of the courses are taught by adjunct professors whose pay is minimal, the student-teacher ratios remain higher than other graduate education, and ABA-accreditation standards for graduate education are slight. Over twenty-five law schools (one out of every seven ABA-accredited law schools) presently offer a graduate degree specializing in taxation, which can only be explained by the belief that tax lawyers need a graduate law degree and the likelihood that these programs are very profitable. Third, since law schools are not permitted by ABA accrediting regulations to offer "majors" in their basic educational program, a school can differentiate itself within the law school market by trumpeting a graduate program which offers a practice specialization. Since graduate level courses are ordinarily open to all students, this marketing tool may entice some entering students to enroll who otherwise might matriculate elsewhere. George Washington University, for example, offers graduate degrees specializing in administrative law, corporate law, criminal law, environmental law, government contracts law, land use law, law and poverty, patent law, tax law and urban law.

Mandatory continuing legal education was first broached in 1971. After a study of several years, the Minnesota Supreme Court instituted mandatory continuing legal education beginning in 1975. Iowa and Wisconsin created similar programs that same year. While only nine states approved a mandatory continuing legal education program in the 1970s, today at least thirty-seven states have some program. The reason given for mandatory continuing legal education was the necessity of ensuring continued attorney competence as 
laws changed. Of course, the connection between continuing legal education and attorney competence was not empirically verified; it was simply assumed.

It is likely that the rush to mandatory continuing legal education was the result of a crisis in confidence in the bar. The Watergate scandal, which resulted in an ABA-required professional responsibility course (or a commitment to teach professional responsibility issues in doctrinal courses) for all law students, as well as the MPRE, encouraged the bar to create programs restoring the public's confidence in the professionalism of lawyers. Mandatory CLE informed the public that lawyers were duty-bound to remain competent and that the state would revoke their license if they failed to meet these competency requirements.

The proliferation of mandatory CLE resulted in the proliferation of organizations supplying programs satisfying CLE requirements. For example, the State Bar of Wisconsin lists over seventy organizations which have been granted general program approval. The best known of these organizations is the National Institute of Trial Advocacy (NITA), formed in 1970 to "contribute to the development of an adequately trained, professionally responsible trial bar, sufficient to serve the needs of justice in the United States."[11] NITA programs draw practitioners from all over the country, and it has now begun to sell casebooks as well as practitioner manuals and guides. Like bar review organizations, NITA and other similar CLE organizations affect law schools in two ways: First, CLE organizations perpetuate the dichotomy between the science of law taught in law schools and the practice of law taught by CLE organizations. Second, like bar review organizations, CLE groups enhance the power of professors, who are over-represented as speakers and panelists in CLE.

A legal specialization program allows an attorney to claim an expertise not just as a licensed lawyer but as a lawyer certified by a board of legal specialization as particularly expert in a defined area of law. The first legal specialization program was instituted in 1971, the same year discussions concerning mandatory CLE began. Both California and Texas developed standards in 1971, and today thirteen states have adopted some legal specialization program. Before the end of the 1970s, the ABA had approved a Model Plan for Specialization. Under the Model Plan, a lawyer must (1) substantially engage in practice in the area of specialty and (2) complete at least ten CLE hours a year in that field in the three years before applying for certification as a specialist. Additionally, a peer review committee assesses the qualifications of each applicant before certifying the applicant.

The legal profession analogized itself to the medical profession, and a number of lawyers argued that the sharply rising curve of knowledge in law, as in medicine, necessitated public recognition of the specialization of legal practice. This scientific analogy allowed lawyers and the public to continue to think of law as a science. The ideology of legal specialization is the attempt to reclaim the scientific "nature" of law. Its instrumental value is in differentiating suppliers of legal services.

The method of specialization in law, unlike the method in medicine, places only a slight burden on the lawyer-applicant. The ABA's "substantial practice" requirement, for example, means a mere twenty-five percent of the lawyer's practice is devoted to that area of practice. The ABA's requirement that a specialist complete ten hours per year of CLE courses is minimal, since most states mandating CLE as a condition of continued licensure require all lawyers, not just specialists, to spend at least ten hours per year in continuing legal education. Certification as a specialist under the ABA Model Plan requires little of the 
lawyer and promises another marketing tool allowing lawyers to declaim their professionalism.

\section{Conclusion}

The transformation of the practice of law from a "trade" into a "profession" was in large part fortuitous. The utility of lawyers to the industrial and financial economies made some lawyers integral parts of American capitalism. This rise in their prestige was consolidated in part by the creation of organizations such as the ABA which fostered the belief in the professionalism of lawyers. The members of the ABA and other elite practitioners supported the emergence of a "scientific" view of law and legal education, a view which also supported the professionalization of law. The embrace by prominent practitioners and elite organizations of the science of legal education increased the prestige and influence of law schools; the profitability of law schools (which resulted in a great increase in their number) and the decline, for various reasons, of legal apprenticeships, made legal education a more popular way of entering the practice of law. The legal professoriate assumed the responsibility of created coherence in law by clarifying and unifying legal doctrines through legal treatises and uniform acts. The rise of the administrative state in the early to mid-twentieth century also solidified the making of a legal profession. The regulation of the economy by the government created a need for more lawyers, particularly lawyers with knowledge in particular legal fields. This expansion of law was channeled by the Restatements and by the creation of continuing legal education.

The study of selected legal institutions in this essay provides only a glimpse of the relationship between the vision of law as a science and the development of the American legal profession. A multiplicity of factors, many of them historically contingent, operated to create the perceptions of lawyers as professionals. The story told here, like all stories, tells us only a little something.

Notes

[1] Anthony Chase, "The Birth of the Modern Law School," Journal of American Legal History 23 (1979); 329.

[2] This section is based on Robert Stevens, Law School (Chapel Hill: U of North Carolina P. 1983); Arthur E. Sutherland, The Law at Harvard (Cambridge: Belknap, 1967); Chase, "The Birth of the Modern Law School"; and materials on legal education collected by the late Frederick Snyder, a former teacher of mine. Other sources used include Richard L. Abel, American Lawyers (New York: Oxford UP, 1989); Wayne K. Hobson, The American Legal Profession and the Organizational Society, 1890-1930 (New York: Garland, 1986); and George Martin, Causes and Conflicts: The Centennial History of the Bar Association of the City of New York, 1870-1970 (New York: Houghton, 1970).

[3] Sutherland, 174-75, quoting Langdell's Preface to Cases on Contracts and the Record of the Commemoration, November Fifth to Eighth, 1886, on the Two Hundred and Fiftieth Anniversary of the Founding of Harvard College (1887).

[4] Much of the following information comes from John A. Matzko, "The Best Men of the Bar: The Founding of the American Bar Association," The New High Priests: Lawyers in Post-Civil War America, ed. Gerard W. Gawalt (Westport, CT: Greenwood, 1984).

[5] Martin, 133. 
[6] Hobson. Compare the system in medicine of training interns and residents at hospitals.

[7] Julius Goebel, Jr., ed., A History of the School of Law: Columbia University (New York: Columbia UP, 1955) 337.

[8] Abel, 249.

[9] Warren A. Seavey, "The Restatement, Second, and Stare Decisis," A.B.A.J. 48 (1962): 317-18.

[10] Most of the facts in this paragraph are derived from Michael L. Swygert and Jon W. Bruce, "The Historical Origins, and Early Development of Student-Edited Law Reviews," Hastings Law Review 36 (1985): 739.

[11] 1990 NITA Brochure.

The author wishes to thank his research assistant, Liz Friday, for her invaluable help with this article. 